\title{
Research on Systems and Mechanisms of Ecological Education of Innovation and Entrepreneurship of "Universities-governments-enterprises" in Local Application-oriented Universities
}

\author{
Guiying Kong \\ International Exchange College \\ Wuzhou University \\ Wuzhou, China 543002
}

\begin{abstract}
The innovation and entrepreneurship education in local application-oriented universities need cooperate with local governments and enterprises. The principle of Ecological education has a rich connotation of interdependence, mutual support, mutual cooperation, responsibilities and the development of benign cycle. So, local universities, governments, enterprises would make their roles clear to further build the development of system and mechanisms of "universities-government-enterprises" ecological education from the management and regulations, coordination, resources sharing, technology interaction, public service platform, incentives and constraints in order to achieve the purpose of fostering innovative entrepreneurial talents together.
\end{abstract}

Keywords-local application-oriented universities; governments and enterprises; innovation and entrepreneurship; ecological education; system and mechanisms

\section{INTRODUCTION}

With the national developing strategy as the service innovation to drive, more and more universities are involving in innovative teaching reform. But adapting to local regional economic development, the current application-oriented

The paper is:

1. Phase result of the Key project of Guangxi higher educational undergraduate teaching reform in 2016 "Research on the Mechanism of Innovation and Entrepreneurship Education System in Application-oriented Universities under the Background of the Transitional DevelopmentTaking Wuzhou University as an Example”, project number: 2016 jgz163.

2. Phase result of the category A General project of Guangxi higher educational undergraduate teaching reform in 2017 "The Innovation and Practice of Talent Cultivation Mode of Experiential Foreign Language Teaching in Local Universities", project number: 2017JGZ309.

3. Achievement of Major project of Wuzhou university-level educational teaching reform in 2016: "The Construction and Practice of Quality Supervision and Guarantee System of Experiential Foreign

Language Teaching in Local Universities", project number: Wyjg2016A001.

4. Phase result of the key research base of humanities \& social sciences in universities in Guangxi -- The research Center of Folk Literature in Xijiang River, (project number: Guangxi Educational Scientific Research [2014] 12).

5. Funded by "Youth and middle-aged Backbone Teachers' Training Program" of Wuzhou University. universities usually have such local characteristics of undergraduate comprehensive type of interdisciplinary, application, teaching research for training applicationoriented high-level technical talents who have these abilities of the employing skill, practical innovation and selfimprovement. However, in reality, due to the reasons of teachers, curriculum, training plan, training mode, most universities can't systematize to train talents on innovation entrepreneurship education. In addition, as far as local enterprises are concerned, they have the strong desire to improve their productivity and competitiveness to make profits. Although they lack of motivation to cooperate with universities, they can provide the resources such as site, funds, manpower, facilities, practical experience which are the good premise and cooperating basis with innovation entrepreneurship education in universities. In terms of local governments, they fail to closely contact with universities and enterprises and play the positive role because of little attention to innovative education, week policies' interoperability on innovative education, out-of-date information, weak economic developing platform, etc.. In view of these, under the background of the current transforming development, this paper argues that local application-oriented universities should fully understand principle of "education ecology", closely joint local governments and enterprises on talents cultivation of innovation entrepreneurship education. The three parties should clear their roles in ecological development to construct such the system and mechanisms of interdepending, mutual supporting, mutual benefit and promoting the benign cycle to ensure that local application-oriented universities can sustain healthy development on innovative education and to meet the urgent needs of our innovative country in new period.

\section{THE CONNOTATION OF ECOLOGICAL DEVELOPMENT OF INNOVATION AND ENTREPRENEURSHIP EDUCATION SYSTEM}

In 1866, Haeckel, a German zoologist, first proposed the "ecology" [1], He defined it as the science to study the 
organisms with their interaction in the same environment. The function of its ecological system is to meet the needs of subjects' growth, to achieve harmonious coexistence with the ecological subjects and the environment. In 1979, Lawrence Archur Cremin, a famous American educator, proposed the concept of educational ecology in his book Public Education that the scholars should use ecological principle to study the education of the material and spiritual environment on development law [2]. Domestic scholars, Lu Junzhen (1998) argued that educational ecology was related to education with its ecological environment, he regarded it as a discipline using its interrelationship and mechanisms as the research objects, which researching core tended to the law of interaction among the educational eco-environment, ecological system and education efficiency [2]. Researching educational ecology can transform a suitable healthy educational activities running ecological environment and protect educational eco-environment so as to realize the educational goal in this stage. The researching essence to the system of educational eco-development belongs to a branch of organizational ecology, which mainly using the ecology on concepts, models, theories and methods to study the organizational structure with the influence of its environment.

The system of educational ecology development of innovation and entrepreneurship in universities is harmonious development through the innovation and entrepreneurship education in universities, it can promote entrepreneurial talents' innovation under the joint action of regular and sustainable developing process among universities, governments, enterprises and other parties. Its purpose is to achieve its basic target of innovation and entrepreneurship education, to guarantee the talents to improve their quality continually in universities, to ensure the talents to fully use the existing resources of the school and the outside potential resources so as to settle their future development for practical entrepreneurship when they step into society, so the system is multiple components which are interdependence, interaction and coordinated development. The local application-oriented universities, as one of the important elements in system, mutually rely on and cooperate with other components, produce a symbiotic "winwin", then benefit, eventually realize the change from innovation and entrepreneurship education in universities to the development of ecological education.

\section{THE ROLES OF "UNIVERSITIES-GOVERNMENTS- ENTERPRISES” IN SYSTEM}

\section{A. Local Governments}

Local governments at all levels are the supporters in the development of application-oriented universities and enterprises. They have the responsibilities to offer the counseling of entrepreneurial plans, propose the policies on research projects and venture investments for universities, In respect of policies, regulations, capital investment, social public service, local governments can utilize the methods of arrangements, planning, fund transfers, resources integration, assistances to guide the talents cultivation in universities and enterprises' development. They could advise universities how to build a new system of innovation and entrepreneurship education to propel their talents' training program, training mode, curriculum setting, discipline construction and to give a specification of industry guidance in order to better effectively connect with the production and local enterprises' development. Local governments can also propel the cooperation among colleges, universities, enterprises and local economic development zone, comprehensive economic experiment area.

Local governments are the regulators and supervisors of policies. Mei Weihui (2016) thought that they were the policymakers, resource providers and quality monitors in the innovation and entrepreneurship education in universities [3]. Through investigating regional economic development, they can make scientific policies for local application-oriented universities to support their training targets, talents standard, development concepts, development blueprint to cultivate those high-quality innovative entrepreneurial talents that local regional economic development needs for propelling the regional economic transformation upgrade development. They cultivate innovation sense and interest from talents' primary and secondary schools. When they enter universities, local governments will focus on training their values, knowledge, researching skills on innovation and entrepreneurship. They supervise the quality of the talents' practice process through the supervision of college administration and educational administration for cultivating high quality original talents to high- efficiency service for society. Local governments are the implementing persons of the policies and measures. Using the capital investment and recourses supply, they make relevant regulations and measures support local enterprises to participate in innovation and entrepreneurship education; to found entrepreneurial innovation funds for university talents and help them carry out the innovation entrepreneurship; or to put university talents' researching funds in place and support the talents' researching activities of the commercialization process. They carry out the tax breaks policies to encourage the enterprises to invest those risky projects which have wide prospects. Only do they implement indeed the operational policies and measures, effectively reduce the entrepreneurial risk of university talents to solve their actual problems [4].

\section{B. Enterprises}

Enterprises are the strongest supporters of innovative education. Enterprises closely tie to the market dynamics, their modes of production and development concept can influence the concept of innovative education in universities. Enterprises support educational activities with manpower, material resources, places, funds and faculties; they give project investments, track for project researches, provide industrial services such as special skills training, etc.. They also build entity hatcheries construction of different disciplines, set up internet startup base, establish talents exchange platform of innovation and entrepreneurship in universities. For the entrepreneurial projects in different areas, different emphasis, the enterprises should provide more professional social services, they set up professional staff and equipment to assist the innovative activities in 
universities, timely accelerate the entrepreneurship programs in early hatching and growth. Meanwhile, the enterprises need provide multi-funding for talents and universities need strengthen the talents' skills to gain the project funding. The enterprises also need simplify procedures to improve the system that the talents obtain the threshold of funds and the project channels of funding.

\section{Local Application-oriented Universities}

1) Building discipline and curriculum system, setting up innovation and entrepreneurship education colleges: Lacking of teachers, equipment, the innovation and entrepreneurship education in many local applicationoriented universities can only be finished by their secondary schools by opening basic courses, specialized courses, elective courses, public elective courses, and minor in specialized courses, innovative projects or practical projects. So, according to local economic reality, local applicationoriented universities need set up the corresponding curriculum system, develop relevant teaching materials create an educational management system and discipline system, and really put the innovative education into the system of educational ecology development. They found the talents educational college on their campus, complete with professional teaching staffs who have rich practical experience and can undertake those works on teaching management, practice, base, capital operation or forming special research teams, etc.. The innovation and entrepreneurship education colleges open their elective courses, experimental classes, practice classes; provide specialty courses for school students. They coordinate various departments such as teaching affairs office, student affairs office, youth league committee, students practice center, employment guidance center. They arrange general courses, undertake creative competitions, construct nursery garden, contact external enterprises and entrepreneurial mentors, etc.. Local application-oriented universities need strengthen the construction of disciplines, stimulate various professional teachers to devote their enthusiasm to innovation and entrepreneurship education and explore diverse interdisciplinary forms.

2) Building various training system for talents: Local application-oriented universities exploit different professional platform, guiding platform, micro-innovative platform to complete the talents training system. Universities optimize teaching modes from heuristic method, exploring, experiential teaching, participate type, collaboration, apprentice type, workshop type, etc.. They embody the enterprises' new craft; new technology, new materials and new equipment to different majors' courses for creating a seamless connect with the practical teaching training system. They build school laboratories, researching centers, experimental practical bases in school and establish practical researching centers out of school; they cooperate with enterprises to establish the integration of the talents teaching training platform by setting up the activities of teaching, practice, scientific research, innovative employment to build a teaching quality safeguard and monitoring system.

3) Integrating the concepts to the personnel training schemes: Guided by the local economic dominant industry, universities optimize the professional disciplines' structure of regional demand to establish a diversified practice base through docking industry standards; mainly build local producing line of the interdisciplinary talents' training on the development of professional competency, the application abilities of job skills. Through cultivating the talents' innovative spirit, consciousness, abilities, critical thinking, universities focus on the process evaluation of talents' abilities. They respect for the individual cognitive differences, highlight the courses assessment to the innovative application process of skills-based, to promote better the concept of curriculum examination for development. Universities should build experience-oriented curriculum system for strengthening students' practical learning, completing the management structure, equipping teachers teams; creating a better learning campus environment to help talents clear the experiential learning concept of entrepreneurship. Schools provide minor courses on entrepreneurship for the students majoring in different disciplines in various secondary colleges. The different secondary colleges develop their own innovative education projects according to their own characteristics of academic disciplines on the personnel training schemes and courses system. As long as students obtain the corresponding credit, they not only gain professional degree, but get the matched degree on innovative education.

4) Expanding educational connotation and its auxiliary methods: Local application-oriented universities pay more attention to foster talents' innovative awareness, knowledge and abilities. Only do the talents fuse the basic skills and creation together, the real productive forces could be transformed from the form of innovation and entrepreneurship. Universities still cultivate students' social responsibility, entrepreneurial thinking and abilities to solve social problems, from these, students can find such solving opportunities of innovation and entrepreneurship projects: environmental pollution, traffic jam, water utilities, etc.. In innovative environment, universities help students further understand the cultural atmosphere, business circumstance, entrepreneurial policies in the different regions. They help them find entrepreneurial opportunities, assist the cooperation among the intercollegiate students to carry out empirical investigation and study, or expand the job market, etc.. Universities can invite entrepreneurial successful people to give lessons, seminars, analyze typical entrepreneurial cases, simulate entrepreneurial process, found entrepreneurial teams, role experience to help students build their own innovative experience. The educational informationalization of quality course needs be 
quickly built in universities; the internet technology is introduced into the students' learning: the high-quality public classes, MOOC, flip online of resource sharing should be given which can guide students to learn and practice independently.

\section{THE FORMATION OF SYSTEM AND MECHANISMS ON "COLLEGE-GOVERNMENT- ENTERPRISE" ECOLOGICAL EDUCATION OF INNOVATION AND ENTREPRENEURSHIP}

\section{A. Making Management and Regulations}

The formulation and implementation of the cooperating regulations are the prerequisite for the development of the healthy circular cooperation among the three parties. Local governments promote the cooperation among them to laws level, they unite universities, industry insides of enterprises to found educational steering committees or councils, confirm the rights, responsibilities, obligations and interests among their three parties in the process of cultivating creative talents from regulations and treaties. They share coeducational mechanism from co-building laboratories, experiment centers, experimental teaching centers, career centers, project researching centers. According to their developing needs, enterprises guide their industry to cooperate with universities, they perfect teaching steering committee of industrial innovation, set up the forecasting mechanism of talents demand and the early warning mechanism of professional settings. They coordinate with universities from training plans, professional layout, course system, teaching material building, practical innovational management system, evaluation criterion, etc.. What "university- enterprise" cooperates is to promote the integration from the road of production -learning-research to promote the transformation of innovational achievements. For fostering the talents adapting to the economic development, they pave the roads and bridges for the talents having the high-end innovative skills that society need [5]. They play decision-making mechanism together to substantively guide talents training target, teaching management, scientific research, and practice problems such as infrastructure construction. Only enacting their own rights and obligations, all parties can promote their deep cooperation and effectively drive personnel training work.

\section{B. Building Coordination Mechanism}

Due to different roles, universities, governments and enterprises must coordinate their interests to establish coordination mechanism, to deeply cooperate form the ways of production-learning-research-use-business. Sometimes, on the one hand, in considerations of regional development, local governments have to keep down educational expenditure, reduce educational resource allocation for lower the running cost; at the same time, they hope that universities can promote the healthy development for local economics and bring the achievements for governments. On the other hand, Local universities shoulder the critical mission of training talents for local development, they have to change training mode, promote teaching quality constantly. Therefore, local financial support exists the contradiction with universities' development. Enterprises' own development and social competition need innovative talents, but enterprises are not willing to invest in education. Besides, due to increasing cost of teacher training, teaching reform, experimental facility, universities can't carry out innovative education just by themselves continually, they also have conflicts. So, as the managers, local governments should fully realize that the three parties are the beneficiaries of upgrading the regional development at last. Local governments make enterprises see that cooperating with universities can quickly train the talents needed by their industrial development and bring more legitimate benefits for them; and investing the educational work, enterprises will the beneficial winners ultimately. As long as coordination mechanism is established, the motivation of the long-term cooperation of the three parties will be strengthened.

\section{Building Resources-sharing Mechanism}

Due to the resource shortages, local universities have difficult to provide talents with funds, venues, equipment, technology, production and environment needed by educational activities of innovation and entrepreneurship. So, universities deeply co-establish resources-sharing mechanism with enterprises to complement the shortage of the old experimental equipment for making up for educational funding gap that governments lack, and lower the costs such as the construction of research centers, innovative laboratories in universities. The most important is that talents can utilize the enterprises' advanced equipment and production techniques to observe, train and research which not only let students learn professional skills, professional practice, but let them get the creative inspiration from knowing the latest technology in enterprises. As local governments, who play the role of overall planning to help universities introduce the obsolete equipment from enterprises to strengthen the basic experimental training equipment? On the basis of resources-sharing with teachers, research institutes and teaching places, enterprises can not only entrust universities to cultivate various applicationoriented talents they need, but jointly research new products, new technologies, and share their achievements in innovative research. Local governments coordinate universities and enterprises to jointly purchase new equipment, to jointly build practical training, technological research centers to provide intellectual support for the technological renewal and enterprises' development.

\section{Establishing High-tech Interactive Mechanism}

According to regional developing demand, the three parties create regional science park, high-tech business incubators, accelerators' experimental areas, personnel business parks which effectively C:IUsers\Users $\backslash A d m i n i s t r a t o r \backslash A p p D a t a \backslash L o c a l \backslash Y o$ udao\ict\Application 17.2.0.0703 \resultuildictlcombine with technical research, production practice, market platform of achievements transformation, thus wholly open the interactive science eco-park form the frame structure of educational ecology development of innovation and entrepreneurship of education, science and technology, researching, industry, business entity. In Science Park, the 
three parties provide sufficient space, completes facilities, high level incubation service, innovative research resources for the enterprises, which will also attract tech-enterprises to come and to incubate. When they learn, develop from interaction, the collection of internal and external resources would be accelerated. The three parties establish technology interaction office, implement the system of decision-making procedure, and build the projects of quality review and feedback system; they will implement co-management system that builds a dynamic assessment mechanism among teachers, students and technicians. They regularly carry out the observation and learning activities in science park which would provide further those services of incubation guidance, promote operation, financing, consulting for all kinds of innovative start-up projects; they actively promote the transformation of high-tech achievements, the incubation of small and medium-sized enterprises, talents' cultivation and carrier construction; continuously consummate the system of technology interaction services. To accelerate the transformation of high-tech achievements and open sharing high-tech resources, the three parties also link resources at home and abroad to construct a higher level of high-tech interaction platform and resource sharing platform.

\section{E. Establishing Mechanism of a Public Service Platform}

To meet the mass needs in network innovation, the three parties build the public service platform for makers' space providing space, places, intelligent workshops, makers' studios accessories supermarkets, high-speed internet, software and hardware for innovative talents. The makers' space provides low-cost workshop, network space, social space and resource sharing space to help creative people to realize their dream. The public service platform provides inexpensive convenient services, sets up the offices to give free office space for the start-up talents. The public service platform also provides life safeguard service; sets up intellectual property service station, small businesses' service center; opens the multi-function training classrooms, laboratories, operation rooms, conference halls, libraries, apartments, etc.. Local governments set up a diversified financial service platform, provide one-stop services such as business, finance and taxation to give value-added services for innovative entrepreneurs. The platform also bring in well-known investors from home and abroad, small trade association and other external institutions to enter the science park who provide financial services for innovative investors.

\section{F. Building Incentive-constraint Mechanism}

The three parties all clear that local universities are the cradles of creative talents' cultivation. Their talents' innovative research of high-tech achievements transforming into productivity can attract the enterprises' investment so as to achieve the aim of incentive innovation in universities reform. As the member of the ecological system, local governments firstly stimulate universities to integrate their teachers resources such as establish professional discipline leaders, backbone teachers, industry enterprise technical backbones, experts, skillful craftsmen that integrate teaching, scientific research, production, technical services as one of professional teachers teams. The three parties issue the principles and implementation methods of mutual engagement between universities and enterprises. They built a professional engineers and technicians' workshop. They build the swap mechanism for full-time or part-time teachers, make them co-participate in professional construction, curriculum development, teaching material compilation, project research which gradually form teaching, application, research, production and service as one of the operating mechanism, which can improve continuously teachers' grasp on practice technology operation, market trend, enterprise culture, at the same time, the theory quality and research level of technicians in enterprises can be improved[7]. Besides, to the positive collaborative education's enterprise, Local governments control the current cooperation rules of university-enterprise, they need make relevant policy mechanism to improve the capital structure, the operating environment, reduce indirectly these obstructing affects due to enterprises' liquidate funds. Local governments establish interests and risk sharing mechanisms to supervise the distribution of fairness interests between universities and enterprises. Local governments raise educational funds from multi-channels and forms, such as establish special funds to attract business investment in education, implement material reward and spiritual reward mechanism to the excellent coenterprises. Local governments build up the risk salvage mechanism to help enterprises to solve such worries that enterprises who actively participate in invest educational projects but fail at last. Local governments can use the funds to implement incentive mechanisms for enterprises, such as financial subsidies, tax exemptions, monetary awards or honorary awards for cooperative enterprises. Meanwhile, raising tax and heavy taxation penalties shall be imposed on those enterprises who intentionally avoid cooperation. With the help of financing, preferential policies and risk safeguard mechanism, enterprises change competitive concept to motivate themselves to get new blood and new forces from teachers and students to enhance the enterprises' own synergies. Local universities provide intellectual technical support for enterprises to seek innovative and entrepreneurial employment for students' which indirectly promote social economic transformation and upgrading. Enterprises provide practical training places for universities to create goods for society and stimulate economic development, but they also need high-tech forces to improve themselves. Local enterprises accumulate connections to cultivate potential markets for social sustainable development. Therefore, the cooperative education can achieve a win-win result and a symbiotic effect. Under the current transformation time, the incentive mechanism of symbiosis effect is an effective incentive strategy to enhance the cooperating efficiency between universities and industries.

\section{CONCLUSION}

Local application-oriented universities need the support and cooperation of local governments and enterprises, they should borrow the principle of ecological education from the perspective of mutual support, mutual cooperation, but responsibilities, benign cycle development which clear that the three parties of "universities-governments-enterprises" can make their roles to further build the development of 
system and mechanisms of ecological education from management, guarantee, coordination, resources sharing, high-tech interaction, public service platform, incentives and constraints in order to achieve the purpose of fostering innovative entrepreneurial talents together. Only do local governments, enterprises and universities give full play to the responsibilities of the roles and fully implement the linkage mechanisms that can effectively achieve the aim of co-cultivating the applied innovative talents.

\section{REFERENCES}

[1] Shuyi Wang, The Russian Ecological Method[M]. Wuhan University Press, 2001: 5.

[2] Junzhen Lu, On Educational Ecological Environment[J].Journal of Li nyi Teacher's College. 1998(4): 59-61.

[3] Weihui Mei, Meng Ying. Innovative Entrepreneurship Education in C hinese Universities: The Role Positioning and Action Strategies of the Government, Universities and the Society[J]. Journal of Higher Educ ation. 2016 (8):9-15.

[4] Zongzhen Jing. Innovation Path of "Government-enterprisecollege" Linkage Resource Integration in Applicationoriented Universities [J]. Journal of Chongqing University of Educati on.2016(7): 120-123.

[5] Xianhua Dai. Construction of a Practice Teaching Platform of the Inte gration of Government, Production, Training, Research and Applicati on by the interaction of universities, government and enterprises[J]. R esearch and Exploration in Laboratory, 2013(6) : 212-213 